\title{
Expanding Criminal Responsibility in Transnational and International Organised Crime
}

\author{
Harmen van der Wilt*
}

DOI: $10.21827 / 59 \mathrm{db} 69227860 \mathrm{f}$

\begin{abstract}
In international criminal law theory, a conceptual divide is made between international crimes stricto sensu (genocide, crimes against humanity, war crimes, aggression) and transnational organised crime. This differentiation sustains the direct, respectively indirect enforcement mechanism: the so called 'core crimes' belong to the subject matter jurisdiction of international criminal tribunals and the International Criminal Court, whereas national jurisdictions aim to counter transnational crimes, by concluding 'suppression conventions' and seeking international cooperation on the basis of the aut dedere, aut judicare principle.

Nevertheless, the division is questioned for being too rigid and simplistic, as the boundaries between the categories are increasingly blurred. On the one hand, political rebel groups and organised crime often unite to challenge the power monopoly of the state, while corrupt governments and private business conspire to exploit the local population (by pillage, deportation from their lands or pollution of the environment). On the other hand, there is an ongoing debate, triggered by the ICC Kenya Decision of March 2010, whether the commission of crimes against humanity is the 'privilege' of states and state-like groups, or whether the category should be expanded to cover larger organisations that are capable of committing such atrocities. In other words, there is a proliferation of state and non-state actors that engage in both 'classic' international crimes (war crimes, crimes against humanity) and transnational crime. These developments have fuelled the plea for supranational law enforcement in respect of transnational (organised) crime, exceeding the realm of inter-state cooperation on a horizontal basis.

This essay will pay a modest contribution to this discussion by arguing that the quest for more effective law enforcement is bedeviled by the perplexity of fitting new patterns of crime and new perpetrators of international crimes into the classic mould of international criminal law. These two aspects are obviously intimately related and should not be considered in isolation. Any initiative to invigorate international criminal law enforcement - by for instance establishing new (international or regional) courts or by expanding the subject matter jurisdiction of existing courts - should therefore pay attention to both the elements of crimes and the modes of criminal liability.
\end{abstract}

\section{Introduction}

Over the course of the last few decades, the boundaries between political crime and transnational organised crime have been gradually blurred. Terrorists have engaged in illicit drug trade, kidnapping and extortion in order to finance their operations, while keeping up the façade of political commitment for PR purposes. Criminal syndicates

Professor of International Criminal Law, University of Amsterdam. 
have contested the state's monopolies on violence and taxation with a view to the perpetuation of their profitable business. Benefiting from weak and fragile states, open borders and sophisticated technology, casual alliances between transnational organised crime and terrorism have become a real challenge for law enforcement authorities all over the world. ${ }^{1}$

International legal responses to transnational organised crime and political crime have been diverse. As is well known, the International Criminal Court (ICC) and international criminal tribunals have jurisdiction over only a limited number of 'core crimes' (genocide, war crimes, crimes against humanity, aggression). Perpetrators of these crimes incur direct criminal responsibility under international law. Whereas these crimes have traditionally been associated with the abuse of state power, it is increasingly acknowledged that they also can be committed by non-state actors that possess the resources and organisational capacity to engage in these crimes, either during armed conflict or outside the context of war. ${ }^{2}$ Criminal law repression of transnational organised crime, on the other hand, has preserved a horizontal, inter-state character. States have entered into so-called 'suppression conventions', in order to invigorate cooperation. These conventions enjoin states to incorporate elements of transnational crimes in their own legislation and assist each other, both in the arrest and prosecution of suspects and the gathering of criminal evidence. ${ }^{3}$ In view of the convergence between transnational organised crime and political crime, this rupture in law enforcement has been increasingly censured as obsolete or outdated. ${ }^{4}$

I do not intend to pursue that discussion in this contribution. ${ }^{5} \mathrm{I}$ would rather like to address an aspect that transnational organised crime and international crime have in common: they are both committed by - or by means of - organisations, and are therefore by definition collective crimes. In summarising the definitional elements of international organised crime, Carrie-Lyn Donigan Guymon points at the 'hierarchical', rigid, or compartmentalized organizational structure that uses internal discipline and thereby

${ }^{1}$ For very forceful analyses of this phenomenon, see Shelley, LI, Dirty Entanglements; Corruption, Crime and Terrorism (Cambridge University Press, Cambridge, 2014); and Makarenko, T, "The Crime-Terror Continuum: Tracing the Interplay between Transnational Organised Crime and Terrorism", 6(1) Global Crime (2004) 129, 133. 'Thus, most criminal and terrorist groups operational in the 1990s and into the twenty-first century have developed the capacity to engage in both criminal and terroristactivities.'

${ }^{2}$ Recent case law of the ICC points in that direction, see Situation in the Republic of Kenya, Decision Pursuant to Article 15 of the Rome Statute on the Authorization of an Investigation into the Situation in the Republic of Kenya, ICC-01/09, 31 March 2010, with Dissenting Opinion of Judge Hans-Peter Kaul.

${ }^{3}$ For a comprehensive analysis of the 'horizontal' system, see Clark, RS, "Offenses of International Concern: Multilateral State Treaty Practice in the Forty Years Since Nuremberg", 57 Nordic Journal of International Law (1988), 49.

${ }^{4}$ See, for instance, Smith, JM, "An International Hit Job: Prosecuting Organized Crime Acts as Crimes Against Humanity", 97(4) The Georgetown Law Journal (2009), 1112; and Schloenhardt, A, "Transnational Organised Crime and the International Criminal Court; Developments and Debates", 24(1) The University of Queensland Journal (2005), 93.

5 The search for the most appropriate system of law enforcement in respect of transnational and international crimes is the central topic of van der Wilt, $\mathrm{H}$ and Paulussen, $\mathrm{Ch}$, eds, Legal Responses to Transnational and International Crimes: Towards an Integrative Approach? (Elgar Publishers, Cheltenham, to be published in 2016 or 2017). For highly sophisticated reflections on the essence of transnational crimes, in relation to law enforcement, see the several publications by Boister, N, "Transnational Criminal Law'?", 14(5) European Journal of International Law (2003), 953; and Id, "Treaty Crimes, International Criminal Court?" 12(3) New Criminal Law Review: An International and Interdisciplinary Journal (Summer 2009), 341; and Id, "Further reflections on the concept of transnational criminal law", 6(1) Transnational Legal Theory (2015), 9. 
protects the leadership (...) from detection or implication in commission of crimes. ${ }^{6}$ It is a conspicuous element that transnational organised crime shares with the 'core crimes' which are typically depicted as 'system criminality'. ${ }^{7}$ The organisational 'prong' raises two issues in the realm of law enforcement. First, one may wonder how the organisational veil can be pierced and the leadership, that pulls the strings but remains behind the screens, can be held criminally responsible. Secondly, it might be attractive and effective to prosecute the organisation as an entity.

This article explores what legal steps have been taken to target the leadership of transnational criminal organisations and to dismantle these organisations by means of criminal law. The system of individual criminal responsibility for core crimes that is briefly discussed in Section Two serves as a normative framework. Section Three will mainly focus on and discuss the relevant provisions on criminal responsibility in the United Nations Convention against Transnational Organized Crime of 2000. In Section Four, I will address some recent initiatives within the area of corporate criminal responsibility. Section Five rounds up with some reflections, pointing out the inherent limitations of criminal law and international relations.

\section{Criminal Responsibility and System Criminality}

Criminal responsibility for international crimes in the strict sense, has been widely discussed in legal doctrine and will therefore only be briefly summarised in this essay. ${ }^{8}$ Nevertheless, it serves as a useful frame of reference for gauging the initiatives in respect of transnational organised crime.

The organisational dimension of core crimes is most clearly expressed in the Joint Criminal Enterprise-doctrine that has been further developed by the International Criminal Tribunal for the former Yugoslavia (ICTY). This concept provides for criminal responsibility for all members of a group that harbour a criminal purpose. With respect to crimes committed by other members, if they have made 'some contribution' and either intended to further the criminal intention of the group or the crimes were a natural and foreseeable consequence of the implementation of the criminal plan. ${ }^{9}$ The application of JCE Doctrine has generally received a critical reception, as scholars have pointed at the rather vague standard of 'some' contribution and at the dilution of the 'common

${ }^{6}$ Guymon, CLD, "International Legal Mechanisms for Combating Transnational Organized Crime: The Need for a Multilateral Convention". 18(1) Berkeley Journal of International Law (2000), 53, 56.

${ }^{7}$ Nollkaemper, A, "Introduction" in Nollkaemper, A and van der Wilt, H, eds, System Criminality in International Law (Cambridge University Press, Cambridge, 2009), 1. 'The term system criminality refers to the phenomenon that international crimes - notably crimes against humanity, genocide and war crimes - are often caused by collective entities in which the individual authors of these acts are embedded.'

${ }^{8}$ See for instance the contributions in Nollkaemper \& van der Wilt, Ibid; and van Sliedregt, E, Individual Criminal responsibility in International Law (Oxford University Press, Oxford, 2012); and Ambos, K, Treatise on International Criminal Law (Oxford University Press, Oxford, 2013), 102-232; and Stewart, J, "The End of "Modes of Liability" for International Crimes", 25(1) Leiden Journal of International Law (2012), 165.

9 The JCE-doctrine has been introduced by the Appeals Chamber of the ICTY in Prosecutor v. Tadić, Judgment, Case No. ICTY-94-1-A, 15 July 1999, paras 185-229 as customary international law and has subsequently been applied in numerous cases, including ICTY, Prosecutor v. Krajišnik, Judgment, Case No. ICTY-00-39/40, 27 September 2006; Id, Prosecutor v. Brđanin, Judgment, Case No. ICTY- 99-36-A, 3 April 2007 and Id, Prosecutor v. Popović et al., Judgment, Case No. ICTY-05-88-T, 10 June 2010. 
purpose' requirement, arguing that it could easily degenerate into 'guilt by association'. ${ }^{10}$ It bears emphasis that the JCE-doctrine serves as a vehicle to expand criminal responsibility over members of a group. It does not provide for criminal responsibility for the group as such. Corporate criminal responsibility is not envisaged in the statutes of the ICC or international criminal tribunals. ${ }^{11}$

Particular attention for the criminal involvement of political and military leaders in core crimes is reflected in the inclusion of 'ordering' and 'inducement' in Article 25 (1), sub $b$ of the Rome Statute. Compared to the Statutes of the ad hoc tribunals, the scope of leadership responsibility is reduced in the Rome Statute, as the latter does not mention 'planning' of international crimes, nor 'conspiracy' in respect of genocide. ${ }^{12}$ Hierarchical relations, typical for the military and of prime importance for the observance of international humanitarian law, underlie the concept of 'superior responsibility' which has been elaborated on and refined in the case law of the ICTY, in particular the Celibicicase. ${ }^{13}$ The notion that those who plan and organise international crimes should not escape criminal responsibility is also - negatively - expressed in the abolition of functional and personal immunities in respect of core crimes. ${ }^{14}$

In its case law, the ICC has departed from the track mapped out by the ICTY. Rather than lumping all 'partners in crime' together under the blanket of JCE, the ICC has made efforts to explain how persons occupying leadership positions employ organiszations in order to commit (international) crimes. Borrowing from the legal concept of Organisationsherrschaft, developed by German scholar Claus Roxin, the (Pre-) Trial Chamber in the Katanga-case in particular has argued that 'indirect perpetration' (committing a crime by means of another person), as mentioned in Article 25 (3), sub a of the Rome Statute, includes 'perpetrations by means of an organization'. ${ }^{15}$ This approach has received mixed reactions in legal literature. Some have wondered whether concepts that had been developed to address tightly organised power structures in modern bureaucracies could be applied in the much more cluttered situations that reign in

10 Compare, for instance, Danner, AM, and Martinez, JS, "Guilty Associations: Joint Criminal Enterprise, Command Responsibility and the Development of International Criminal Law", 93(1) California Law Review (2005), 150; and Ohlin, JD, "Three Conceptual Problems with the Doctrine of Joint Criminal enterprise", 5 Journal of International Criminal Justice (2007), 89; and Badar, ME, "'Just Convict Everyone!', Joint Perpetration from Tadić to Stakić and back again", 6(2) International Criminal Law Review (2006), 293.

${ }^{11}$ See Article 25, United Nations, Rome Statute of the International Criminal Court (1998) 2187 UNTS 90 (Rome Statute): 'The Court shall have jurisdiction over natural persons pursuant to this Statute' (italics added). In a similar vein Article 5, UN Security Council, Statute of the International Criminal Tribunal for Rwanda (1994) (ICTR Statute) and Article 6, UN Security Council, Statute of the International Criminal Tribunal for the Former Yugoslavia (1993) (ICTY Statute). On the vain efforts to introduce corporate criminal responsibility in the Rome Statute, see van der Wilt, H, "Corporate Criminal Responsibility for International Crimes: Exploring the Possibilities", 12(1) Chinese Journal of International Law (2013), 4377.

12 Article 4 (3), sub b ICTY, respectively 2 (3), sub b ICTR Statute qualify conspiracy to commit genocide as a punishable offence. 'Planning' of international crimes is included as a ground for individual responsibility in Article 7 (1) of the ICTY Statute, respectively Article 6(1) of the ICTR Statute.

${ }^{13}$ ICTY, Prosecutor v. Delalić and others, Judgement, Case No. IT-96-21-T, 16 November 1998, paras 330401. Superior responsibility features in Art. 28 of the Rome Statute and in Article 7(3) ICTY, respectively Article 6(3) of the ICTR Statute.

${ }^{14}$ Article 27 of the Rome Statute; Article 7(2) of the ICTY, respectively Article 6(2) of the ICTR Statute.

${ }^{15}$ Situation in the Democratic Republic of the Congo in ICC, Prosecutor v. Katanga and Chui, Decision on Confirmation of the Charges, ICC-01/04-01/07, 30 September 2008, paras 477-518; confirmed by the Trial Chamber in its judgement in Prosecutor v. Katanga, 7 March 2014, paras 1403-1416. See, however, the critical dissenting opinion by Judge Christine Van den Wyngaert. 
African countries. ${ }^{16}$ Others have drawn attention to the doctrine's quality of putting the limelight on both organisations and their leadership as 'starting point of attribution in international criminal law.' ${ }^{17}$

We may observe, by way of intermediate conclusion, that the international criminal tribunals have well understood the relevance of organisations and their leadership in system criminality, but that they are still searching for the legal concepts that most adequately capture these aspects. ${ }^{18}$

\section{Criminal Responsibility of Leadership and Organisations in Transnational Organised Crime}

The United Nations Convention against Transnational Organized Crime (2000) (hereafter: UNCTOC) was launched as a catch-all convention, intended to improve law enforcement and international cooperation in respect of all kinds of offences committed by transnational organised crime. ${ }^{19}$ Article 2, sub (a) defines the central topic of the convention - an 'Organized criminal group'- as

'a structured group of three or more persons, existing for a period of time and acting in concert with the aim of committing one or more serious crimes or offences established in accordance of this Convention, in order to obtain, directly or indirectly, a financial or other material benefit.'

The scope of application of the Convention is limited to offences that are 'transnational in nature', which means that the interests of more than one State are affected. In the realm of targeting criminal organisations and their leadership, the Convention displays a number of interesting features. It calls upon States parties to criminalise

"conduct by a person who, with knowledge of either the aim and general criminal activity of an organized criminal group or its intention to commit the crimes in question, takes an active part in: a) Criminal activities of the organized criminal group; b) Other activities of the organized criminal group in the knowledge that his or her participation will contribute to the achievement of the above described criminal aim." 20

The wording shows more than a fleeting resemblance to JCE Doctrine, as expounded in the previous paragraph. Just like in JCE, it is not necessary that the person himself

${ }^{16}$ See Weigend, T, "Perpetration through an Organization: The Unexpected Career of a German Legal Concept", 9(1) Journal of International Criminal Justice (2011), 91-113.

17 Compare Ambos, K, "Command responsibility and Organisationsherrschaft: ways of attributing international crimes to "the most responsible" in Nollkaemper \& van der Wilt, supra nt 7, 157. Compare also Olàsolo, $\mathrm{H}$, "The Application of Indirect Perpetration through Organised Structures of Power at the International Level" in Olàsolo, H, Essays on International Criminal Justice (Hart Publishing, Oxford and Portland, 2012), 120, who agrees with Ambos that the notion of indirect perpetration through organized structures of power is today a serious option to hold criminal leaders to account, adding that 'application of notions of accessorial liability in this type of case (...) relegates superiors to a secondary role which does not correspond to their actual relevance.'

${ }^{18}$ See van der Wilt, HG, "The Continuous Quest for Proper Modes of Criminal Responsibility", 7(2) Journal of International Criminal Justice (2009), 307-314.

${ }^{19}$ UN General Assembly, United Nations Convention Against Organized Transnational Crime, 15 November 2000, UN 2225 UNTS 209 (UNCTOC).

20 Article 5 (1), sub a, under ii, UNCTOC. 
engages in the very crimes; activities that sustain the general purpose suffice, if done with the intention to further the criminal aim or in the awareness that they will contribute to such an objective. ${ }^{21}$ Whether 'taking an active part' is more demanding than 'some contribution' is difficult to say. Presumably, both qualifications would also encompass relatively passive acts, like 'being on the look-out' in case of burglary. ${ }^{22}$ Whereas the UNCTOC in this respect closely follows the precedents of international criminal case law, at other points it remarkably deviates from this normative framework. Firstly, the Convention announces the joyeuse rentrée of conspiracy liability. After all, Article 5 (1), sub a (i) stipulates that States should consider as criminal offences (either as an alternative to or together with) conduct defined in Article 5 (1), sub a, (ii)

"Agreeing with one or more persons to commit a serious crime for a purpose relating directly or indirectly to the obtaining of a financial or other material benefit and, where required by domestic law, involving an act undertaken by one of the participants in furtherance of the agreement or involving an organized criminal group."

The insertion 'where required by domestic law etc.' refers to the circumstance that some common law jurisdictions require, as well as an agreement, an 'overt act'. ${ }^{23}$

Secondly, the UNCTOC demonstrates a specific awareness for the position of leaders within organised criminal groups. Article 5 (1), sub b enumerates a broad gamut of possible involvement, clarifying that 'organizing, directing, aiding and abetting, facilitating or counselling the commission of serious crime involving an organized criminal group' involves criminal responsibility. ${ }^{24}$

Finally, Article 10 of the Convention provides for liability of legal persons for participation in serious crimes involving an organised group. Section 2 of this provision adds that this liability may be criminal, civil or administrative, a reassurance that meets the concerns of states that are adamant to introduce criminal corporate liability. ${ }^{25}$ Corporate liability co-exists with criminal liability of natural persons (Article 10 (3)) and each State Party 'shall, in particular, ensure that legal persons held liable in accordance with this Article are subject to effective, proportionate and dissuasive criminal or noncriminal sanctions, including monetary sanctions. ${ }^{26}$ It is a formulation that is reminiscent of the language in the famous Greek Maize case of the European Court of Justice. ${ }^{27}$ Article 10 of the UNCTOC has served as a model for similar provisions in other conventions on specific transnational crimes. ${ }^{28}$

It is not surprising that the approaches of the UNCTOC and the Statutes of the international criminal court and international criminal tribunals towards criminal organisations and their leaders diverge. Profit-making is the raison d'etre of commercial enterprises and it is therefore more likely that they get involved in shady affairs that yield material benefits. There is therefore a certain urgency in properly regulating the corporate

\footnotetext{
${ }^{21}$ The provision bears also resemblance to Article 25 (3), sub d of the Rome Statute.

${ }^{22} \mathrm{Mc}$ Clean, D, Transnational Organized Crime; A Commentary on the UN Convention and its Protocols (Oxford University Press, Oxford, 2007), 64.

${ }^{23} I d, 63$.

${ }^{24}$ Emphasis added

${ }^{25}$ Compare Thomas, W, "Societas delinquere non potest? A German Perspective" 6(5) Journal of International Criminal Justice (2008), 927-945.

${ }^{26}$ Article 10(4), UNCTOC.

${ }^{27}$ European Court of Justice, Commission v Greece, Case 68/88, ECR 2965, 21 September 1989, para 24.

${ }^{28} \mathrm{See}$, for instance, UN Convention against Corruption, 2349 UNTS 41 (2003), Article 26; Council of Europe, Convention on Cybercrime, ETS No. 185 (2001), Article 12.
} 
(criminal) liability of such entities. A second reason for divergence is directly related to the different systems of law enforcement governing international crimes and transnational organised crime. At first blush, the (re-)introduction of 'conspiracy' in the UNCTOC seems rather spectacular. However, as indicated above, States Parties must make a choice between criminalising conspiracy and participation in a criminal enterprise. The system of indirect criminal law enforcement that is predicated on the action of domestic jurisdictions requires greater flexibility. Drafters of suppression conventions can therefore afford to be bolder in suggesting far-reaching solutions, because, at the end of the day, states still have the discretion 'to take it or leave it'. I will return to this topic in the final section. Meanwhile, the different legal reactions on criminal organisations and their leaders are perhaps problematic in view of the convergence between international crimes stricto sensu and transnational organised crime. A more coherent, integrated approach is therefore worthy of consideration.

\section{Criminal Responsibility in the Light of Convergence between International Crimes and Transnational Crimes: Some New Developments}

Some internationalised or 'hybrid' criminal tribunals have subject matter jurisdiction over both international crimes and national offences that derive from the state that is involved in the establishment of these tribunals. An interesting example is the Special Court for Sierra Leone that combines jurisdiction over crimes against humanity, war crimes in noninternational armed conflicts, other serious violations of international humanitarian law and 'crimes under Sierra Leonean law' ${ }^{29}$ Another interesting feature of the Sierra Leone Court is its focus on 'those bearing the greatest responsibility for serious violations of international humanitarian law' (Article 1 of the Statute). ${ }^{30}$ While the limitation of 'the most responsible' has resulted in the prosecution and trial of political and military leaders wielding authority during the civil war, the inclusion of domestic crimes has come to naught: none of the defenders was charged with one or more of these domestic offences. Whether these issues are related is a matter of conjecture.

Nonetheless, the Special Court for Sierra Leone has set the stage for other hybrid tribunals and regional courts. The recently established Special Court in Kosovo has subject matter jurisdiction over crimes against humanity and war crimes, but also over a host of offences under Kosovo's law. ${ }^{31}$ This latter category includes corruption, so it transpires that the Kosovo Court's jurisdiction blends core crimes and transnational crimes. Arguably the most interesting initiative is the intended extension of the African Court of Justice and Human Rights with a Criminal Chamber. In May 2014, the African Union adopted the 'Malabo-Protocol' with an Annex that provided for the establishment

${ }^{29}$ United Nations, Statute of the Special Court for Sierra Leone, U.N. SCOR, UN Doc. S/2002/246 (2002), Article 5 .

${ }^{30}$ Whether this should be understood as a jurisdictional requirement or as a prosecutorial guideline was a matter of fierce legal contestation. For more details see the probing analysis of Jalloh, C, "Prosecuting Those Bearing "Greatest Responsibility": The Contributions of the Special Court for Sierra Leone", in Jalloh, CC, ed, The Sierra Leone Special Court and its Legacy; The Impact for Africa and International Criminal Law, (Cambridge University Press, Cambridge, 2014) 589-623.

${ }^{31}$ Compare Article 6 of the Law on Specialist Chambers and Specialist Prosecutor's Office, Law No.05/ L053, 3 August 2015, available at <assembly-kosova.org/common/docs/ligjet/05-L-053\%20a.pdf> (accessed on 8 March 2016). 
of such an International Criminal Law Section. ${ }^{32}$ The subject matter jurisdiction of this future regional court contains a mixture of international crimes stricto sensu and transnational crimes. ${ }^{33}$ The definitions of the core crimes have, by and large, been copied from the Rome Statute (Articles 28B - 28D), while the subsequent provisions (Articles $28 \mathrm{E}-28 \mathrm{~L}$ Bis) define the other offences. ${ }^{34}$

For the purpose of this essay, it is highly interesting that Article $28 \mathrm{~N}$ on Modes of Responsibility is largely modelled on the corresponding provision in the UNCTOC:

"An offence is committed by any person who, in relation to any of the crimes or offences provided for in this statute: (i) Incites, instigates, organizes, directs, facilitates, finances, counsels or participates as a principal, co-principal, agent or accomplice in any of the offences set forth in the present Statute (...)." ${ }^{35}$

Moreover, like the UNCTOC, the Malabo Protocol provides for corporate criminal liability. Article $46 \mathrm{C}$ of the Protocol stipulates that '[f]or the purpose of this Statute, the Court shall have jurisdiction over legal persons, with the exception of States.' The subsequent sections of the provision elaborate on the way the mens rea of corporations can be established.

As the African Criminal Chamber has not yet come into being, it is clearly impossible to predict how it will perform in practice. ${ }^{36}$ However, the architecture of its Statute is promising, as it displays an understanding of the close connection between modes of criminal responsibility and the nature of specific crimes.

\section{VI.1. Some Final Reflections}

Criminal law enforcement acknowledges the importance of organisations and their leadership in both traditional international crimes and transnational organised crime. However, in countering these phenomena, it faces considerable difficulties. The reasons for this are not difficult to grasp. Criminal law has a natural aversion against collective responsibility; because guilt - one of the leading moral principles sustaining criminal law - is essentially an individual issue. This explains the reluctance of the Nuremberg Tribunal to accept the notion of criminal organisations as a tool to identify and punish their members. ${ }^{37}$ Organisations are skilful in concealing the involvement of managing

\footnotetext{
${ }^{32}$ Assembly of States Parties to the African Union, Draft Protocol on Amendments to the Protocol on the Statute of the African Court of Justice and Human Rights, adopted by the $23^{\text {rd }}$ Ordinary Session of the Assembly, held in Malabo, Equatorial Guinea, 27 June 2014, with Annex: Statute of the African Court of Justice and Human and Peoples' Rights.

${ }^{33}$ Article 28A of the Malabo Protocol indicates that the Court shall have the power to try persons for genocide, crimes against humanity, war crimes, the crime of unconstitutional change of government, piracy, terrorism, mercenarism, corruption, money laundering, trafficking in persons, trafficking in drugs, trafficking in hazardous wastes, illicit exploitation of natural resources, and the crime of aggression.

${ }^{34}$ The 'special part' ends with a provision on the Crime of Aggression that, with the necessary modifications, copies Article $8 \mathrm{~b}$ is of the Rome Statute.

${ }^{35}$ Emphasis added.

${ }^{36}$ For a largely critical assessment, see Murungu, CB, who contends that the African Criminal Court is created out of resentment against and in order to outwit the ICC, "Towards a Criminal Chamber in the African Court of Justice and Human Rights", 9 Journal of International Criminal Justice (2011), 10851088.

${ }^{37}$ Membership of a criminal organisation like the SS was only a punishable offence if the defendant had knowledge of the criminal purpose and had voluntarily acceded to the organisation. On this topic Pomorski, S, "Conspiracy and criminal organization" in Ginsburgs, G and Kudriavtsev, VN, eds, The
} 
directors and these latter are therefore difficult to insulate for the purpose of holding them criminally responsible.

International criminal law and transnational criminal law diverge in their approaches towards criminal organisations and their leadership. As suggested above, this can probably be attributed to the distinctions between the 'direct and the indirect' enforcement model, to use the terminology of Bassiouni. ${ }^{38}$ The drafters of the Rome Statute have developed, for a limited number of core crimes, a General Part of (substantive) criminal law, containing concepts of criminal responsibility and grounds for excluding criminal responsibility. ${ }^{39}$ These provisions are tightly and precisely defined, because they require the consent of all States Parties. Within the context of the indirect enforcement model, such a creation of a General Part is inconceivable - at least at the global level - because it is predicated on decentralised law enforcement by states. They will not be easily persuaded to sacrifice their historically grown concepts and idiosyncrasies. The result is that suppression conventions either contain rather vague and open concepts, or leave states parties the choice between alternatives. The convention may introduce corporate liability, but the states parties have the freedom to accomplish this by means of criminal, civil or administrative law. This is conducive to diverging interpretation and implementation of criminal law, which may be regrettable, but is probably inevitable.

One of the future developments that may break the stalemate is the emergence of a regional criminal court that could symbolise the rapprochement between the direct and the indirect enforcement model. States that have closer cultural and political affinity would probably be sooner inclined to establish a court that transcends the rigid division between international and transnational crimes and that would be able to apply the concepts of criminal responsibility that match the nature of those crimes. ${ }^{40}$

\section{www.grojil.org}

Nuremberg Trial and International Law (Kluwer Academic Publishers, Leiden, 1990), 213 and Jørgensen, NHB, "Criminality of Organizations under International Law" in Nollkaemper and van der Wilt, eds, supra nt 7, 202-206.

38 Bassiouni, MC, Introduction to International Criminal Law: Second Revised Edition (Martinus Nijhoff Publishers, Leiden, 2012), 22-27.

${ }^{39}$ Articles 22-33, Rome Statute, Part 3 - General Principles of Criminal Law 9.

${ }^{40}$ Blomsma, CJ, "The Need to Identify a General Part of Criminal Law for the EU" in Marianne Hirsch Ballin, MH, et al, eds, Shifting Responsibilities in Criminal Justice; Critical Portrayals of the Changing Role and Content of a Fragmented Globalizing Law Domain (Eleven International Publishing, Utrecht 2012), 125 who acknowledges the urgency of introducing a General Part of criminal law 'when a system of direct enforcement enters into force'. 